\title{
How BPS-Statistics Indonesia to Handle The Effectiveness of Information System of Public Budgeting Management?
}

\author{
Wawan Kurniawan ${ }^{\text {a* }}$, A. Aziz Sanapiah ${ }^{\text {b }}$ \\ ${ }^{a}$ Badan Pusat Statistik, Jakarta, Indonesia \\ ${ }^{b}$ Politeknik STIA LAN, Jakarta, Indonesia
}

\section{ARTICLE INFORMATION}

\section{Article history:}

Date Submission: 21 March 2021

First Revision: 28 March 2021

Accepted: 05 April 2021

Available Online: 10 April 2021

Keywords: good governance, effectiveness, Public Budgeting Management, BackOffice Information System

\section{ABSTRACT}

The BPS-Statistics Indonesia tried to take a step to realize good governance, especially in conducting good budget management by implementing an information system of public budgeting management known as the BackOffice Information System. The purpose of this study is to find out how the effectiveness of the implementation of the BackOffice Information System at BPS. This study uses a qualitative method by conducting case studies in BPS Headquarter (Jakarta). Conducting online interview to 59 operators and users, as well as conducting deep interview to 10 key informants. The result shows that the implementation of the BackOffice Information System is effective and practical because this information system is accurate and timely in presenting data and budget information, integrated with several other information systems. Users and key informants also are satisfied with the performance of this information system. The implementation of Back Office also contributes to increasing the realization of the budget and the achievement of BPS performance and to maintaining the Financial Statements performance: Unqualified Opinion (from BPK-the Audit Board of the Republic of Indonesia).

\section{INTISARI}

Badan Pusat Statistik (BPS) berupaya mewujudkan tata kelola pemerintahan yang baik, khususnya dalam melakukan pengelolaan anggaran yang baik dengan menerapkan sistem informasi pengelolaan penganggaran publik bernama Sistem Informasi BackOffice. Tujuan dari penelitian ini untuk mengetahui seberapa efektif implementasi Sistem Informasi BackOffice di BPS. Penelitian ini menggunakan metode kualitatif dengan melakukan studi kasus di kantor pusat BPS (Jakarta). Dengan melakukan wawancara online kepada 59 pengguna, serta melakukan wawancara mendalam kepada 10 narasumber utama. Hasil penelitian menunjukkan bahwa penerapan Sistem Informasi BackOffice efektif dan praktis karena sistem informasi ini akurat dan tepat waktu dalam menyajikan data dan informasi anggaran. Pengguna dan narasumber utama juga puas dengan kinerja sistem informasi ini. Penerapan Back Office juga berkontribusi pada peningkatan realisasi anggaran dan pencapaian kinerja BPS serta menjaga kinerja Laporan Keuangan: opini Wajar Tanpa Pengecualian (dari BPK-Badan Pemeriksa Keuangan Republik Indonesia). 


\section{Introduction}

Recently, Indonesian public services show a strong commitment to implementing e-governance systems. The E-Government Development Index (EGDI) shows that EDGI ranks of Indonesia increasing performance. By trend, Figure 1 shows that EGDI Indonesia among ASEAN countries was ranked 7th out of 10 ASEAN countries in 2018. Prior to the EGDI 2018, Indonesia's EDGI ranking in 2018 increased nine rankings from 2016. However, based on the publication of the United Nations E-Government Survey 2018, Indonesia's 2018 EGDI ranked 107 out of 192 countries with a value of 0.5258 out of a maximum value of 1 , slightly below the world average EGDI value of 0.5491 (United Nations, 2018, p. 225).

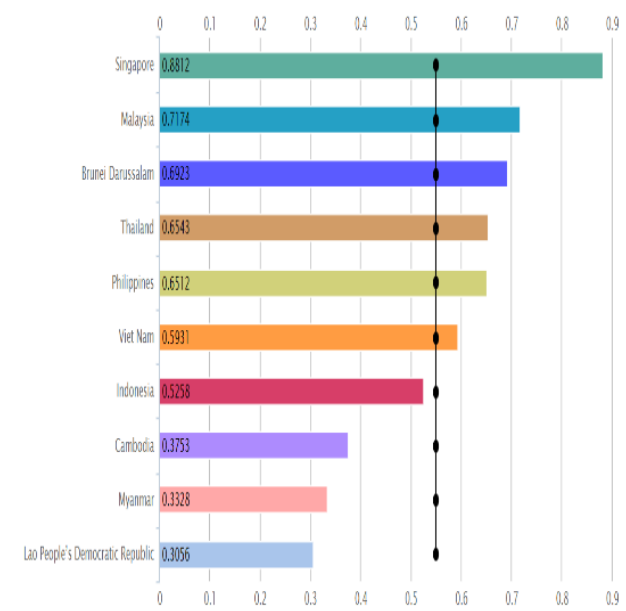

Figure 1 Ranked E-Government Development Index (EGDI) Countries of ASEAN 2018

Source: publicadministration.un.org

Several developing countries have implemented egovernment to improve public services according to the characteristics of their respective countries (El Gohary, 2017, p. 7510). The Malaysian government, for example, has used the e-government (MyEG application) as one of the government's initiatives to people. The government believes that this effort is an amenity for the people and the business community in solving a wide variety of matters (Kamarudin et al., 2018, p. 27). On the other hand, the Ministry of Finance of the Republic of Indonesia has also implemented e-government in the field of budget and financial management with the launch of several information system applications, such as the Treasury and State Budget System (SPAN), Institutional Level Financial Application Systems (SAKTI), Accrual Based Accounting System (SAIBA) (Akhmadi, 2017, p. 52). The provincial government of the special capital region of Jakarta has also implemented e-government in government financial management called e-budgeting. EBudgeting is a system developed to accelerate the government's planning and budgeting process (Rahman et al., 2019, p. 95)
The manifestation of e-government implementation in each ministry/ government institution or regional government is different but has the same goal: good governance (Nurhakim, 2014, p. 406). Aiming to realize good governance, a ministry/government could conduct good budgeting governance. Furthermore, BPS-Statistics Indonesia takes into account to perform good budget governance. Since mid-2018, BPS has implemented an information system of public budgeting management known as BackOffice Information System. The BackOffice Information System is an integrated information system starting from planning, management, budget use, and budget monitoring at BPS.

BPS aims to achieve several goals by implementing the BackOffice Information Systems, such as: to increase accountability in the use of the budget, facilitating the financial reporting system, and performing the autobudget use process. In addition, BPS aims to manage structured documentation and to monitor the use of the budget in real-time. Meanwhile, with the BackOffice Information System, BPS could perform deep systematics analysis material to determine the next budget planning that is more effective and efficient. Finally, BPS could maintain the status of Unqualified Opinion (WTP) from the Audit Board of the Republic of Indonesia (BPK) on the BPS Financial Statements. Prior to 2018, BPS ran budget management system manually and yet did not implement budget management system support. As a result, some errors and biases are often found in budget management, such as the budget minus, because the use of the budget exceeds the available budget ceiling.

Implementation of the BackOffice Information System is a pilot project based on the information systems of public budgeting management in the BPS Headquarter, yet not in the BPS Regional Office. This research was conducted to explore how the effectiveness of the BackOffice Information System implementation in the public budgeting management at BPS Headquarter.

\section{Theory}

\subsection{Budget Theory in Public Sector}

Many researchers and practitioners give insight into budgeting theory in public sectors; especially in developing countries (see Rubenstein, 2002; Blocher, et. al, 2007; Surianti \& Dalimunthe, 2017). According to Rubenstein (2002), budgeting in the public sector is a plan for introducing program deals with objectives and goals within a period, including an estimate of resources required, usually compared with past periods and showing future requirements.

Also, Rubenstein (2002) promotes several functions of budgeting in public sectors, such as follows: (a) a national and regional development planning tool; 
(b) a control tool; (c) a fiscal policy tool; (d) a political tool; (e) a tool for coordinating and communicating; and (f) a tool for performance appraisal.

Likewise, Khusaini (2019) states that budgeting in the public sector to achieve development goals for fulfilling the basics need of public sectors, such as financing electricity, clean water facility, public health, education, etc.

While Blocher et al, (2007) proposed that budgeting is a process or method for preparing a budget. A process of continually projecting operations and projects and then reflecting financial implications. Budgeting also related to the process of determining the amount of fund allocation for each program and activity in monetary units. The budgeting is a detailed plan for the acquisition and use of financial resources and others for a certain period, especially one fiscal year. Likewise, Venning (2009) points out that some developing countries conduct budgeting in public sectors on a calendar year basis, such as Indonesia's budgeting.

Surianti \& Dalimunthe (2017) argue that the budgeting in government and public sector has a function to connect tasks to be performed by the number of resources required to implement them. With budget management, an organization can limit the spending commensurate with reception, maintain balance and prevent excessive spending above the limits. In the government sector, the budget has technical aspects and also political aspects are strongly influenced by the economic situation, public opinion, and the various levels of government, interest groups, the press, and politicians.

Recently, budgeting in public sectors is reforms from the traditional system (centralized) to New Public Management (NPM) spirits (decentralized). With the spirit of New Public Management (NPM), developing countries conduct budget reforms to achieve transparency, value for money, efficiency, and effectiveness of budgeting system in public service provisions. Many researchers point budget and budgeting system in line with NPM philosophy, especially at five sectors specifically in relation to five financial management aspects (i.e. market-oriented, budgeting, performance management, financial reporting, and auditing systems) (Khusaini, 2019).

\subsection{Indonesia Budgeting System}

In the explanation of Law 17/2003 concerning State Finance, it is stated that a budget is a tool for accountability, management, and economic policy. As an instrument of economic policy, the budget functions to realize economic growth and stability and income distribution to achieve the objectives of the state (Hawkesworth et al, 2009, p. 6). To achieve the objectives and functions of the budget, the House of Representatives (DPR) or the Regional Legislative
Council (DPRD) and the government have an important role in the process of preparing and determining the budget as an elaboration of the main rules stipulated in the 1945 Constitution (UU No.17/2003).

The central government budgeting is contained in the State Budgeting (APBN) approved by the DPR, and the regional government budget is contained in the Regional Budget (APBD) approved by the DPRD. The APBN is a form of state financial management that is stipulated annually by law. APBD is a form of regional financial management that is stipulated annually by Regional Regulation.

\subsection{Information Systems}

Information systems and information technology are important because we live in an era that almost all of our activities always use a computer, laptop, mobile phone, or on the internet every day (Al-Mamary et al, 2014, p. 333). The information system has become so pervasive in daily business process activities, both in the fields of accounting, finance, operational management, and other activities (Marakas \& O'Brien, 2017, p. 5). Information systems have an important role in institution business processes. The role of information systems can increase the efficiency and effectiveness of business processes, help manager's decision-making, improve service, and be able to increase competitive advantage (Zeng et al, 2020, p. 1).

The information system is a combination of two words, system and information. According to McLeod (Darmawan \& Fauzi, 2013, pp. 2-4), a system is a group of elements that are integrated with the same goal to achieve the same goals, and information is the result of data processing that gives meaning or meaning and is useful or useful in increasing certainty. Meanwhile, information systems are a combination of people, hardware, software, communication networks, data resources, and policies and procedures for storing, recovering, changing, and distributing information in an organization (Marakas \& O'Brien, 2017, p. 6).

McLeod (Darmawan \& Fauzi, 2013, p. 2) said that a qualified and effective information system must have the following characteristics:

a) Accurate. The information system can present data and information that reflects the real situation. The information must be error-free and must not be misleading. Accurate also means that information must reflect its purpose. Testing of this matter is usually carried out through testing conducted by two or more different people, and if the results of these tests produce the same results, then the data and information produced by the information system are considered accurate (Sugiyantari \& Titisari, 2018, p. 95); 
b) Timely. The information system must be timely in conveying information. Being on time here means that information must be available or available when the information is needed. Information received must be timely. Information that is outdated or late does not have good value for users so that if used as a basis for decision making and policies will be fatal (Romayah et al., 2014, p. 616);

c) Integration. The information system is integrated with other information systems. Integrated can mean the existence of interrelationships between one information system with other information systems, and each information system can share the same database at almost the same time (Suryaningrat \& Utama, 2018, p. 6); and

d) User Satisfaction. The information system provides satisfaction for its users. User satisfaction is a response and feedback that appear after the user using the information system.

\subsection{BackOffice Information System}

The BackOffice Information System is an integrated information system ranging from budget planning, budget management, budget use, and budget monitoring and evaluation (BPS, 2019, p. 16). This information system was built to support the automation of the existing budget management system in each work unit in BPS. The current BackOffice Information System is the second generation BackOffice Information System which is the development of the first generation, which is still partial between the modules and is managed by a third party.

The BackOffice Information System, as an information system of public budgeting management at BPS, began to be implemented at the BPS Head Office in mid-2018. However, it has only been used by several work units, and development has been carried out simultaneously. Since the beginning of 2019, the BackOffice Information System has been officially implemented and used in all work units at the BPS Head Office.

The purposes of implementing the BackOffice Information System are as follows:

a) Help facilitate and ease the work in budget management and financial reporting processes;

b) Change the budget management process from manual to automatic through the system and minimize errors in budget management caused by human error factors;

c) Create a neat and structured process of managing a budget and financial documentation;

d) Monitor budget users in real-time and accurately;

e) Increase the effectiveness of the use of the budget and the means to maintain the status of WTP opinion from BPK on BPS financial statements; and f) The information generated from the system is used as evaluation material to determine the next budget planning, which is more efficient and effective.

The BackOffice Information System application is used by all echelon three and echelon two of subject matter, Commitment-Making Officer (PPK), budget admin, treasurer admin, and Budget Authority (KPA) at the BPS Head Office. Following is the BackOffice Information System workflow for the stage 1 expenditure request process (see Figure 2).

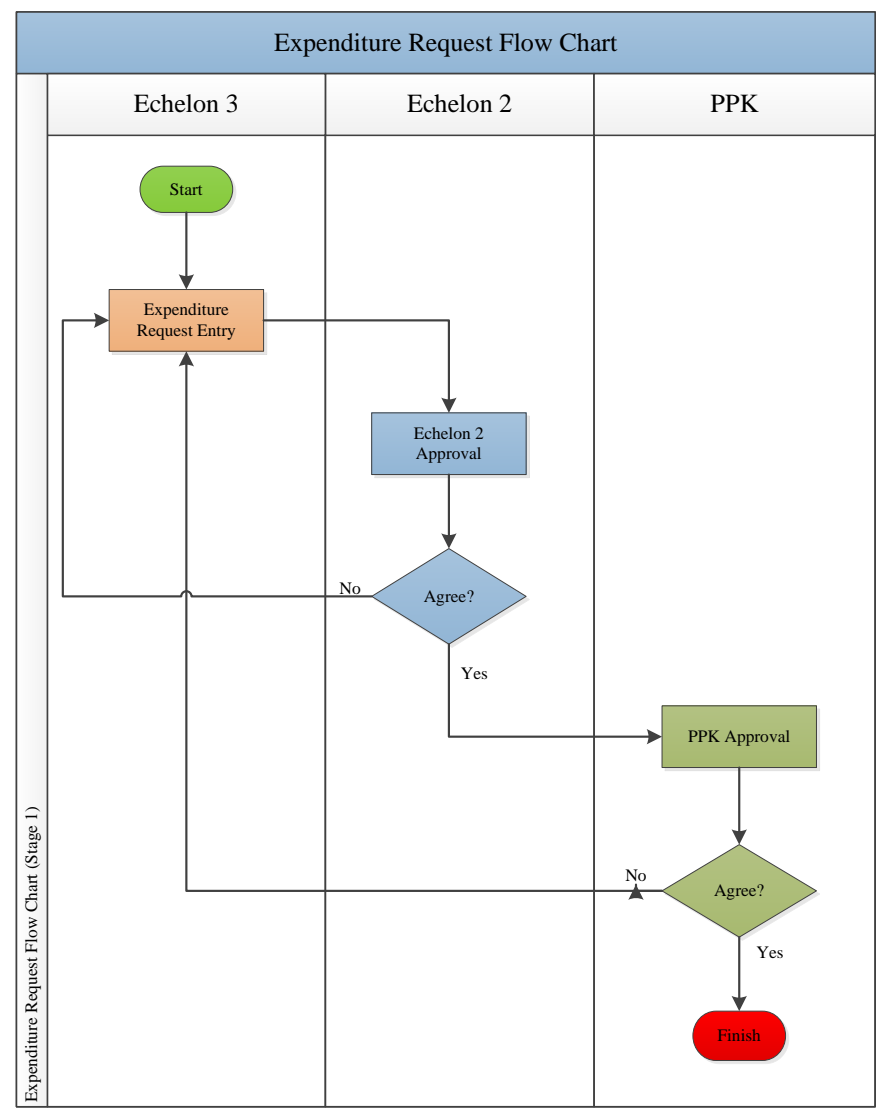

Figure 2 The Flow Chart of Expenditure Request (Stage 1)

Source: Research observation results, 2021

\subsection{Prior Research}

Many prior researchers seek the answer for the implementation of e-governance in public budgeting with several findings in various public sectors areas in developing countries (see Zaidi, 2017; Kochanova et al, 2019; Sofyani \& Prayudi, 2018; Siregar, 2017; Pangestika \& Sari, 2016; Hashim \& Piatti-fünfkirchen, 2018; Khoirunnisa et al, 2017; Rahantoknam et al, 2017)

Zaidi (2017) found a strong relationship between the perceived quality of e-government services (Indian Etax Service) with system quality, information quality, service quality, and community satisfaction. Furthermore, public trust shows a direct relationship with 
the perceived quality of e-government services and the perceived effectiveness of e-governance services.

Kochanova et al, (2019) examine that implementation of e-filing systems reduces tax compliance costs as measured by the number of tax payments, the time required to prepare and pay taxes, likelihood, and frequency of firms being visited by a tax official, perception of tax administration as an obstacle, and incidence of bribery.

Sofyani \& Prayudi (2018) argues that the effectiveness of performance-based budgeting with egovernment information systems in local government (Yogyakarta Provincial Government) had a positive influence on budget absorption, and the accountability also had a positive influence on the use of performance information to practice the arrangement of performancebased budgeting.

Siregar (2017) shows that the SINTAG (Bill Control Information System) in the Treasury Section of the BPK Finance Bureau was quite effective. The SINTAG is considered effective because it meets the requirements of information systems considered to be quality, namely aspects of information accuracy, timeliness of information, the relevance of information, and completeness of the information.

Pangestika \& Sari (2016) conclude that the financial statements produced by the Regional Management Information System (SIMDA) at the Regional Financial and Asset Management Revenue Service (DPPKAD) of Tegal Regency can be understood by the public, representatives of the people, investors, and the government. Furthermore, the financial statements produced by the SIMDA are relevant, reliable, and comparable. The SIMDA based on results with a phenomenological approach is effective.

Hashim \& Piatti-fünfkirchen (2018) show that investing in financial management information systems can lead to a wide array of budget management improvements. Khoirunnisa et al, (2017) find that several indicators of successful implementation of e-budgeting to benchmark how e-budgeting managed to create good governance. Rahantoknam et al, (2017) demonstrates that the quality of information generated by Financial SIMDA in BKAD of Southeast Maluku Regency can be understood, relevant, reliable, and comparable.

\section{Research Methods}

The study used a qualitative method with case studies in BPS Head Office. The study was conducted in pandemic Covid-19. This research uses primary and secondary data. Primary data collection was carried out through online interviews with 10 key informants, observation, and distributing online questionnaires to 59 users of the BackOffice Information System.
Meanwhile, secondary data collection is carried out through documents review, such as BPS financial statements, BPS performance report, etc.

\section{Results and Discussion}

\subsection{Results}

The purpose of this study is the authors want to know how the effectiveness and success story of the implementation of the information system of public budgeting management to realizing good budget governance at BPS. Good budget governance is part of the embodiment of good governance. The focus of this research is on the implementation of the BackOffice Information System, which is one of the information systems of public budgeting management used at BPS.

An information system is effective and qualified if it satisfied the requirements of several aspects, namely accurate, timely, integrated, and user satisfaction. The authors explored key informants and respondents to obtain data and information related to these four aspects and other aspects of the BackOffice Information System application. The authors also observed and examined documents related to the BackOffice Information System application to complete the data and information which are required.

The implementation of the BackOffice Information System as a budget management information system in BPS shows such follows, in four aspects:

\subsubsection{Accuracy}

One important aspect of the quality of an information system is the aspect of accuracy. An information system can be consider..ed qualified and effective if the information system can present accurate data and information. Accurate information is information that fits the actual situation, free of errors, and not biased or misleading. To find out whether the information is considered accurate, testing two or more people as key informants were conducted. If the information they get is the same, then the information is considered accurate.

Based on the results of exploration to key informants and respondents, also supported by observations and document reviews, data were obtained that the information presented by the BackOffice Information System application was quite accurate, although not completely perfect. Some things that can be used as benchmarks that the BackOffice Information System is considered to be accurate enough are as follows.

First, the subject matter cannot submit expenditure requests beyond the available budget ceiling or if the budget is not yet available. The BackOffice Information System will automatically reject the expenditure request 
if the proposed budget exceeds the available budget or the budget is not yet available.

Second, the minus budget has not been found, because the subject matter cannot use the budget beyond what has been set. A predefined budget cannot be increased or reduced by subject matter. The subject matter can only revise the budget between accounts in the Detailed Budget Allocation (POK) subject matter concerned, but the amount of the budget ceiling remains in balance.

Third, the reduction in requests for revision of the POK from the subject matter and the reduction in budget burdens at the treasurer. Before implementing the BackOffice Information System application, requests for revision of the POK and budget loading errors reached more than 400 errors per year. So the presence of the BackOffice Information System application encourages budget managers to be disciplined in managing budgets according to the rules.

Fourth, the process of approval and monitoring of expenditure requests and POK is carried out in stages, starting from the subject matter echelon 3 , echelon 2, to PPK. Thus, the accuracy of the budget can be monitored properly and errors in the use of the budget can be minimized.

Fifth, the data and information presented in the BackOffice Information System are the same as the data and information in the budget, financial, and subject matter sections.

The BackOffice Information System is also equipped with a dashboard and functions to monitor budget conditions and the progress of administration of budget use (such as expenditure requests, SPJ issuance, SP2D issuance, etc.) in each subject matter. The dashboard and monitoring functions are the controls for each subject matter and the section authorized to monitor the conditions and realization of the budget so that the accuracy and suitability of the budget absorption can be maintained properly. This fact confirms that the BackOffice Information System is considered to be accurate to present budget management information at BPS.

The authors also requested an evaluation from key informants and respondents regarding the accuracy of the BackOffice Information System with a value of 1 to 10 , where a value of 1 means very inaccurate and the number 10 is very accurate. The result is that most key informants give a value of 8 , meaning that the BackOffice Information System is accurate.

\subsubsection{Timeliness}

Timeliness is another important aspect of an information system. Information systems are considered qualified and effective if they can present information and data promptly and in real-time. In the era of the development of technology and information, the speed and presence of information are required. Late or out-ofdate information can hurt stakeholders or leaders in making decisions or policies. Information that is too late or obsolete becomes worthless, and can even lead to errors in decision making or policy.

Based on the information obtained from key informants and respondents, it is known that the data and information presented by the BackOffice Information System are real-time. Users can obtain the latest budget data and information in their work units from the BackOffice Information System application anytime and anywhere while connected to the BPS network. For security reasons, only users registered in the database can access the BackOffice Information System. Users who will access the BackOffice Information System from outside the office can use Virtual Private Network (VPN) access via https://smart.bps.go.id.

The BackOffice Information System is equipped with a dashboard and features that function to monitor the current budget conditions of each work unit. Information on the latest budget conditions is displayed in real-time on the BackOffice Information System application dashboard. The timeliness of the BackOffice Information System application in presenting the latest budget information is very helpful for budget managers at BPS when leaders or stakeholders need the latest budget data and information.

In general, although not completely perfect, the BackOffice Information System has been able to present budget management information at the BPS Head Office promptly. However, there are still some shortcomings in the aspect of timeliness for the implementation of the BackOffice Information System. These shortcomings arise because of the lack of user discipline that causes a time lag for the BackOffice Information System in presenting budget information. The problem that is often found is operator delays in entering the realization of the use of the budget on the BackOffice Information System.

\subsubsection{Integration}

An information system is considered qualified and effective if the information system is integrated with other systems. The purpose of the information system is to produce information and facilitate work for its users. To achieve these objectives, an information system must be related to other business process instruments. Information systems cannot stand alone without the support of information systems or other instruments. Hence, the integration aspect is another important aspect of an information system.

The BackOffice Information System currently not integrated with all information systems in BPS, especially information systems related to budget and finance. But, the BackOffice Information System has 
been integrated with the Information System of Human Resouces (SIMPEG) and the Information System of Employee Attendance (PRESENSI ONLINE). The BackOffice Information System uses BPS employee data and information from the SIMPEG. Meanwhile, for the presence of BackOffice Information System attendance uses data and information from the PRESENSI ONLINE. In this context, one name will appear in one activity only. Because when an employee's name is blocked in one activity (for example, on a business trip), the employee's name will not appear again in other activities at the same time.

The BackOffice Information System is currently not integrated with the BPS Budget Planning Information System (IPlan), formerly known as the Work and Budget Plan System (SIREKA ONLINE) because there are still database structure differences between the BackOffice Information Systems and IPlan. The BackOffice Information Systems developer is bridging between the BackOffice Information System database and the IPlan. It is expected that the third generation of the BackOffice Information System has been integrated with the IPlan. The BackOffice Information System is also not integrated with existing applications in the finance bureau, such as the Institutional Level Financial Application System (SAKTI), Accrual Based Accounting System (SAIBA), and the Management and Accounting Information System for State Property (SIMAK-BMN) since all of these applications are financial applications published by the Ministry of Finance. At present, the BackOffice Information System has not been integrated with information systems originating from outside BPS.

Currently, the BackOffice Information System is implemented right at the BPS Head Office. BPS Regional Office (BPS Province Office and BPS Regency/ Municipal Office) have not yet implemented this information system. The BackOffice Information System is a pilot project for managing the budget information system at BPS. A third-generation BackOffice Information System is currently being developed that allows it to be implemented in the BPS Regional Office and integrated with other information systems. It is targeted in early 2021, there will be a trial implementation of the BackOffice Information System application at the BPS Regional Office. If the implementation in the BPS Regional Office is successful, it is also possible to be implemented in other government institutions.

\subsubsection{User Satisfaction}

The aspect of user satisfaction is often used as an illustration of the success of an information system. User satisfaction with information systems is determined by the user's perception of satisfaction with the attributes that exist in an information system (attribute satisfaction) and satisfaction with information provided by an information system (information satisfaction) that is felt by the user under the wishes and expectations of users. The development of information systems is intended to facilitate users in completing their work. The information system is considered successful and effective if the information system can facilitate its users in completing their work. Conversely, if an information system complicates and burdens the work of its users, then the information system is considered a failure.

Based on the results of exploration to key informants and respondents who are all users or involved in the management of the BackOffice Information System, it can be seen that the BackOffice Information System is quite easy to understand and use by its users. The authors ask key informants and respondents to provide an assessment from 1 to 10 where a value of 1 means that it is very difficult to understand and use, and a value of 10 means that it is very easy to understand and use. The results show that the majority $(49,2 \%)$ gave an 8 rating, meaning that the BackOffice Information System is easy to understand and use by its users (see figure 2).

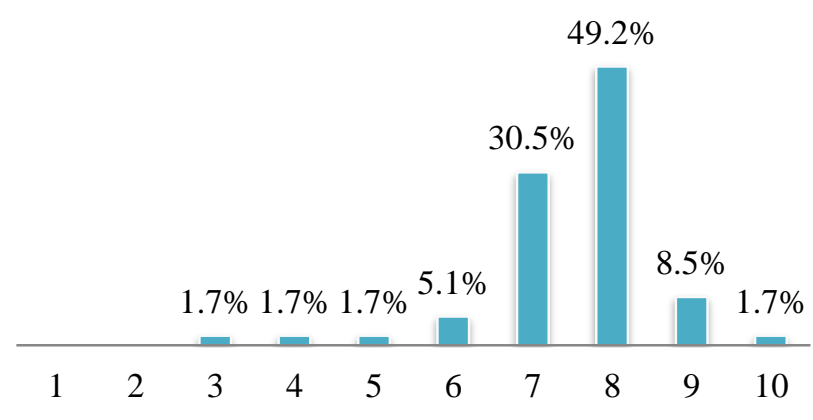

Figure 2 Evaluation of the BackOffice Information System Ease

Source: Research data processing results, 2021

The authors also asked key informants and respondents whether the BackOffice Information System application helped ease their work in managing the budget, by assessing 1 to 10 , where a value of 1 means very burdensome and a value of 10 means very mitigating. Most of the results $(55,9 \%)$ give a value of 8 , meaning that the BackOffice Information System helped ease their work in managing the budget in their respective work units (see figure 3). There are $88.1 \%$ of Key informants and respondents who state that after the implementation of the BackOffice Information System, the budgeting management in their work units becomes faster and more precise. These results indicate that the BackOffice Information System is successful and effective in helping budget management work at BPS.

Overall, the BackOffice Information Systems users are satisfied with the performance of this application. This can be seen from the results of the evaluation of the key informants and respondents who most $(50,8 \%)$ give a value of 8 , meaning they are satisfied with the 
performance of the BackOffice Information System (see figure 3 ).

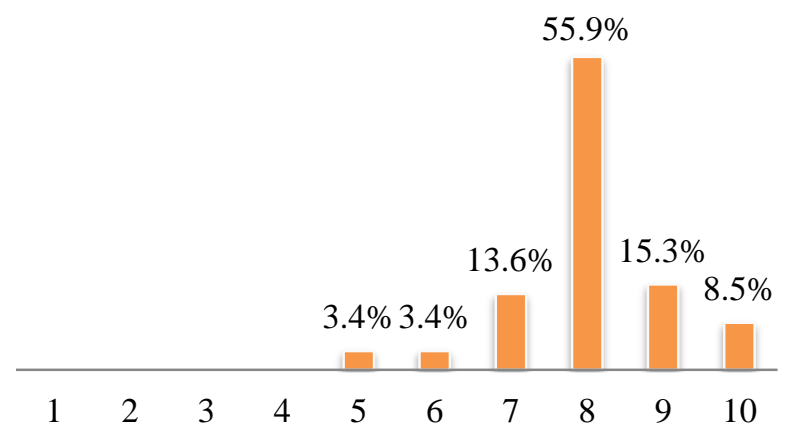

Figure 3 Evaluation of the Role of The BackOffice Information Systems in Assisting Budget Management Work

Source: Research data processing results, 2021

Overall, the BackOffice Information Systems users are satisfied with the performance of this application. This can be seen from the results of the evaluation of the key informants and respondents who most $(50,8 \%)$ give a value of 8 , meaning they are satisfied with the performance of the BackOffice Information System (see figure 4).

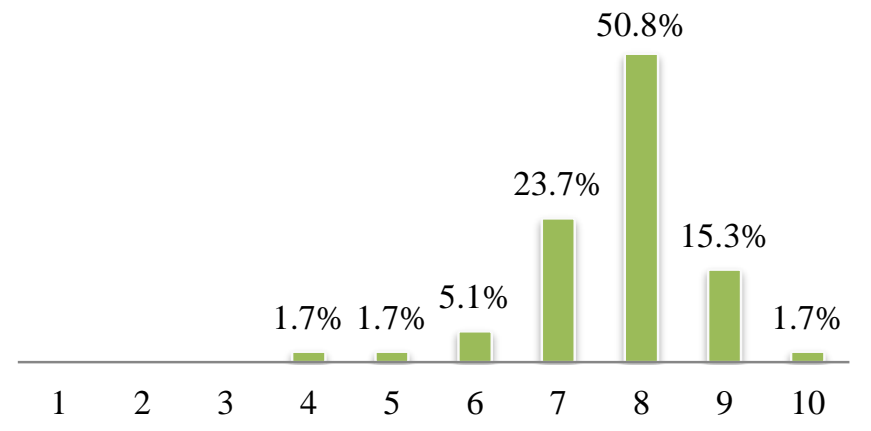

Figure 4 Evaluation of The BackOffice Information System User Satisfaction

Source: Research data processing results, 2021

\subsubsection{Effectiveness of The BackOffice Information System Implementation}

Effectiveness is a measure of the success of an organization in achieving its objectives, especially for the information system organization. If an information system successfully achieves its objectives, then the information system is effective. The main purpose of the information system is to help facilitate users in completing work. Besides, the purpose of the information system is to change the work that is usually done manually to automatically through the system to minimize errors.

Referring to the objectives of the information system above and the discussion of user satisfaction aspects in the previous section, the BackOffice Information System as a budget management information system in BPS, according to researchers, has been running effectively. This is also supported by statements from key informants and respondents. The researcher asks key informants and respondents to provide an assessment of the effectiveness of the BackOffice Information System implementation at BPS. Rating in the form of numbers 1 to 10 , where a value of 1 means very ineffective, and a value of 10 means very effective. The results show that the majority $(46,6 \%)$ give them a value of 8 , meaning that the implementation of the BackOffice Information System is effective. There are even $6,9 \%$ who give a value of 10 , which means they consider the implementation of the BackOffice Information System to be very effective (see figure 5).

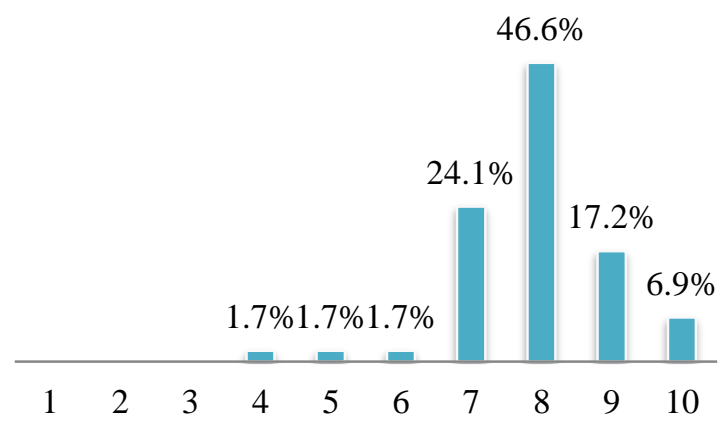

Figure 5 Effectiveness Evaluation of the BackOffice Information System Implementation Source: Research data processing results, 2021

Unfortunately, there are no regulations that form the legal basis for implementing the BackOffice Information System as an information system of public budgeting management at BPS. Even though the regulation is important to bind all parties in BPS involved in managing the budget to be disciplined in managing the budget in their respective work units according to the rules through the BackOffice Information System. Therefore, the implementation of the BackOffice Information System can run optimally.

\subsubsection{Budget Realization and Performance Achievement}

The purpose of implementing the BackOffice Information System as an information system of public budgeting management at BPS is the realization of good budget governance. One thing that can be used as a benchmark is the realization and performance achievements. Budget realization and performance achievements are a form of accountability of the performance of a government institution for the implementation of programs/ activities and budget management. The realization of budget and performance achievements is currently still a reference in measuring the extent to which budget governance and governance are carried out properly.

Implementation of the BackOffice Information System is carried out in all work units in the BPS Head Office in early 2019. Budget realization is calculated by 
comparing the realization of budget absorption with the budget ceiling. The results showed that the average budget realization in 2019 after the implementation of the BackOffice Information System at the BPS Head Office was very good, which is $90,07 \%$ or an increase of $6,50 \%$ from $2018(83,58 \%)$ before the implementation of the Information System BackOffice. The same thing also happened at BPS RI, the realization of the 2019 budget was very good, namely $94,86 \%$ or an increase of $3,71 \%$ from 2018. The development of the 2016-2019 budget absorptions can be seen in Figure 6 below.

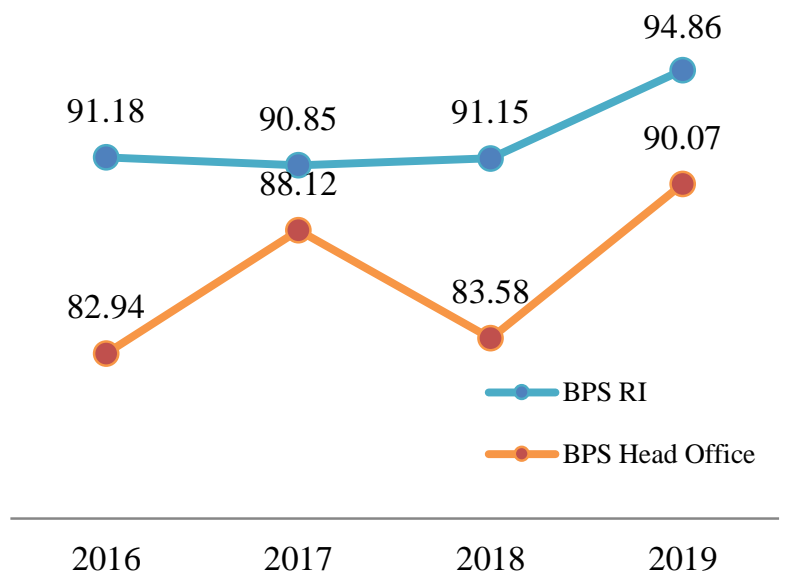

Figure 6 Progress of Budget Absorptions of BPS RI and BPS Head Office of 2016-2019 (Percent)

Source: Research data processing results, 2021

The authors suggest that the implementation of the BackOffice Information System has a positive impact on the budget governance at the BPS Head Office. The increasing of the budget realization can be considered as an indicator of good budget governance at BPS.

The achievements of the BPS RI and the BPS Head Office's performance for the past four years show an everincreasing trend. In general, the performance of the BPS was very good. In 2019 the achievement of BPS RI's performance of $112,54 \%$ increased from 2018 $(112,04 \%)$. The trends of the performance of BPS RI and BPS Head Office can be seen in Figure 7 below.

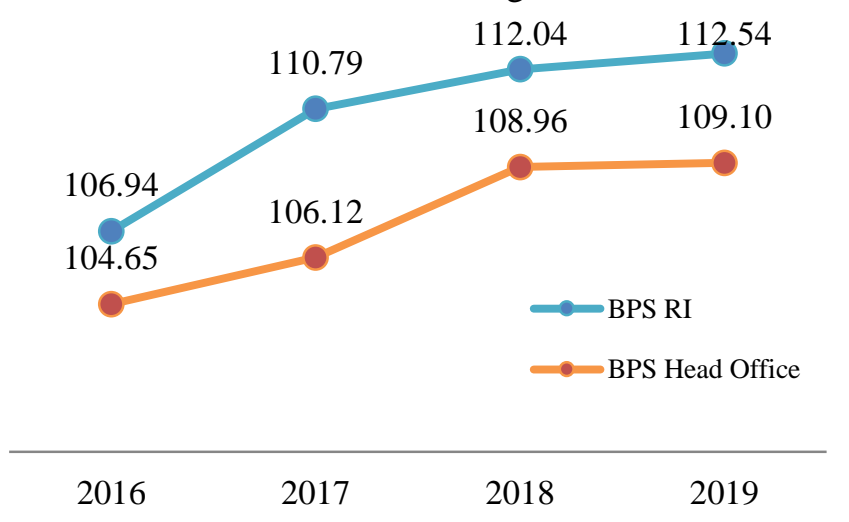

Figure 7 Trends in Performance of BPS RI and BPS Head Office of 2016-2019 (Percent) Source: analysis result, 2021
BPS has been able to maintain a WTP opinion from BPK on BPS financial statements over the past few years. It indicates that the budget management at BPS is good. Table 1 shows the BPK opinion achieved by BPS for the past four years.

Table 1 BPK Opinion on BPS Financial Statements of 2016-2019

\begin{tabular}{|l|l|l|l|}
\hline 2016 & 2017 & 2018 & 2019 \\
\hline WTP & WTP & WTP & WTP \\
\hline
\end{tabular}

Source: BPS Performance Report of 2019

\subsection{Discussion}

By conducting the research, the authors show that by supporting e-governance information systems named the BackOffice Information System, BPS could maintain highly achieve performance in financial statements transparency. These findings support Rubenstein (2002) that public budgets promote a tool for performance appraisal.

Other findings support existing literature (Pangestika \& Sari, 2016; and Siregar, 2017) that the effectiveness of budgeting with information systems have a positive influence on budget absorptions, and accountability, and performance appraisal in local governments and ministry. While three existing types of research demonstrate the effectiveness of public budgeting through e-governance information systems in two local governments (Pangestika \& Sari, 2018), and a ministry office (Siregar, 2017) this research demonstrates the effectiveness of public budgeting through the support of information systems at BPS.

\section{Conclusion}

We conclude that the implementation of the BackOffice Information System as an information system of public budgeting management at BPS is running effectively. The BackOffice Information System is considered qualified and effective, because this information system is accurate and timely in presenting data and budget information, integrated with several other information systems, and users are satisfied with the performance of this information system. The implementation of the BackOffice Information System also made a positive contribution to increasing the realization of the budget and the achievement of BPS's performance and was able to maintain the WTP opinion of BPK on BPS financial statements. This shows that budget management at BPS is running well.

For the optimal implementation of the BackOffice Information System at BPS, it is necessary to make regulations as the legal basis governing the management of the BackOffice Information System. To improve the performance of the information system of public 
budgeting management at BPS, the BackOffice Information System also needs to be integrated more with other information systems related to budget and financial management. The BackOffice Information System should also be implemented immediately in the BPS Regional Office so that they also get the same benefits from this information system.

\section{References}

Akhmadi, M. H. (2017). Evaluasi Dukungan Organisasi Terhadap Implementasi E-Government: Studi Kasus Sistem Aplikasi Keuangan Negara. Jurnal Manajemen Keuangan Publik, 1(2), 51-62. doi: 10.31092/jmkp.v1i2.144.

Al-Mamary, Y. H., Shamsuddin, A., \& Aziati, N. (2014). The Role of Different Types of Information Systems in Business Organizations : A Review by Yaser Hasan Al-Mamary, Alina Shamsuddin, A.H. Nor Aziati. International Journal of Research, 1(7), 333-339.

Blocher, E. J., Chen, K. H., Cokins, G., \& Lin, T. W. (2007). Manajemen Biaya Penekanan Strategis. Jakarta: Salemba Empat.

BPS. (2017). Laporan Kinerja Badan Pusat Statistik 2016. Jakarta: BPS.

BPS. (2018). Laporan Kinerja Badan Pusat Statistik 2017. Jakarta: BPS.

BPS. (2019a). Laporan Kemajuan Reformasi Birokrasi Badan Pusat Statistik Tahun 2018. Jakarta: BPS.

BPS. (2019b). Laporan Kinerja Badan Pusat Statistik 2018. Jakarta: BPS.

BPS. (2020). Laporan Kinerja Badan Pusat Statistik 2019. Jakarta: BPS.

Darmawan, D., \& Fauzi, K. N. (2013). Sistem Informasi Manajemen. Bandung: Remaja Rosdakarya.

El Gohary, E. M. (2017). E-government Implementation in Developing Countries: A Literature Review. International Journal of Computers \& Technology, 16(1), 7510-7524. doi: 10.24297/ijct.v16i1.8371.

Hashim, A., \& Piatti-fünfkirchen, M. (2018). Lessons from Reforming Financial Management Information Systems A Review of the Evidence. No. 8312; WPS8312, Issue January.

Hawkesworth, I., Blöndal, J. R., \& Choi, H. D. (2009). Budgeting in Indonesia. OECD Journal on Budgeting, 9(2), 1-31. doi: 10.1787/budget-9$5 \mathrm{ks} 72 \mathrm{wv} 89 \mathrm{p} 48$.

Kamarudin, S., Omar, S. Z., Bolong, J., \& Osman, M. N.(2018). E-Government Services Implementation: Is it a Need? International Journal of Academic Research in Business and Social Sciences, 8(11), 22-29. doi: 10.6007/ijarbss/v8-i11/4881.

Khoirunnisak, R., Arishanti, D., \& Vebriant, D. D. (2017). Penerapan E-budgeting Pemerintah Kota
Surabaya dalam mencapai good governance. Prosiding Seminar Nasional Dan Call For Paper Ekonomi Dan Bisnis (SNAPER-EBIS 2017), 249256.

Khusaini, M. (2019). Penganggaran Sektor Publik. Malang: Universitas Brawijaya Press.

Kochanova, A., Hasnain, Z., \& Larson, B. (2019). Does E-Government Improve Government Capacity? Evidence from Tax Compliance Costs, Tax Revenue, and Public Procurement Competitiveness. In American Historical Review (No. 7657; WPS7657, Vol. 124, Issue 2). doi: 10.1093/wber/lhx024.

Marakas, G. M. and O'Brien, J. A. (2017). Pengantar Sistem Informasi (6th ed.). Jakarta: Salemba Empat.

Nurhakim, M. R. S. (2014). Implementasi E-Government Dalam Mewujudkan Transparansi Dan Akuntabilitas Sistem Pemerintahan Modern. Jurnal Ilmu Administrasi Media Pengembangan dan Praktik Administrasi, 9(3), 403-422. doi:10.1073/pnas.0407076101.

Pangestika, A., \& Sari, Y. P. (2016). Efektivitas Penerapan Sistem Informasi Manajemn Daerah (SIMDA) pada Dinas Pendapatan Pengelolaan Keuangan dan Aset Daerah (DPPKAD) Kabupaten Tegal. Seminar Nasional IPTEK Terapan (SENIT), $1-4$.

Rahman, R. A. T., Irianto, G., \& Rosidi, R. (2019). Evaluation of E-Budgeting Implementation in Provincial Government of DKI Jakarta Using CIPP Model Approach. Journal of Accounting and Investment, 20(1), 94-114. doi: 10.18196/jai.2001110.

Rahantoknam, T. A., Tinangon, J. J., \& Mawikere, L. M. (2017). Analisis Penerapan Sistem Informasi Manajemen Daerah (SIMDA) Keuangan Pada Badan Keuangan Dan Aset Daerah Kabupaten Maluku Tenggara. Going Concern: Jurnal Riset Akuntansi, 12(2). doi: 10.32400/gc.12.2.18058.2017.

Romayah, S., Suroso, A. I., \& Ramadhan, A. (2014). Evaluasi implementasi E- Government di Instansi XYZ. Jurnal Aplikasi Manajemen (JAM), 12(4), 612-620.

Rubenstein, R. (2002). Providing Adequate Educational Funding: A State-by-State Analysis of Expenditure Needs. Public Budgeting \& Finance, 22(4), 73-98.

Siregar, F. R. H. (2017). Efektivitas Penggunaan Sistem Informasi Pengendalian Tagihan (SINTAG) pada Bagian Perbendaharaan Biro Keuangan Badan Pemeriksa Keuangan Republik Indonesia. Jakarta: Politeknik STIA LAN Jakarta.

Sofyani, Hafiez., \& Prayudi, Made Aristia. (2018). Implementasi Anggaran Berbasis Kinerja di Pemerintah Daerah dengan Akuntabilitas Kinerja 
"A". Jurnal Ilmiah Akutansi dan Bisnis, 13(1), 5464.

Sugiyantari, D., \& Titisari, P. (2018). The Effectiveness Implementation of The Regional Financial Management Information System Cloud At The Jember Regency. International Journal of Research Science \& Management, 5(5), 94-98. doi:10.5281/zenodo.1254391.

Surianti, M., \& Dalimunthe, A. R. (2017). The Implementation of Performance Based Budgeting in Public Sector (Indonesia Case: A Literature Review). International Journal of Developing and Emerging Economies, 5(2), 52-67.

Suryaningrat, A. A. A. M., \& Utama, I. M. S. (2018). Analisis Penerapan Sistem Informasi Pengelolaan Keuangan Daerah (Sipkd) Pada Pemerintah Provinsi Bali. Jurnal Buletin Studi Ekonomi, 23(1), $1-16$.

United Nations. (2018). E-Government Survey 2018: Gearing E-Government to Support Transformation Towards Sustainable and Resilient Societies. New York: UN. doi: e-ISBN: 978-92-1-055353-7.

Venning, P. (2009). Impact of budget support on accountabilities at the local level in Indonesia. OECD Journal on Budgeting, 9(1), 1-29. doi: 10.1787/budget-v9-art5-en

Zaidi, S. F. H. (2017). E-Government Services Effectiveness Evaluation Framework (E-GEEF): A Case Study of Indian E-tax Service. London Metropolitan University.

Zeng, F., Lee, S. H. N., \& Lo, C. K. Y. (2020). The Role of Information Systems in The Sustainable Development of Enterprises: A Systematic Literature Network Analysis. Sustainability (Switzerland), 12(8), 1-31. doi: 10.3390/SU12083337. 